\begin{tabular}{|c|c|c|}
\hline & $\begin{array}{l}\text { International Journal of Environment, Agriculture and Biotechnology } \\
\text { Vol-6, Issue-4; Jul-Aug, } 2021\end{array}$ & $(\theta)=$ \\
\hline IJEคB & $\begin{array}{c}\text { Journal Home Page Available: } \text { https://ijeab.com/ } \\
\text { Journal DOI: 10.22161/ijeab }\end{array}$ & \\
\hline
\end{tabular}

Article

Peer-Reviewed Journal

\title{
Varietal screening of Cucumber in Sundarharaicha Municipality, Morang, Nepal
}

\author{
Ashok Sah ${ }^{1 *}$, Prabhat Swar ${ }^{1}$, Santosh Kumar Yadav $^{1}$, Sanjib Chaudhary ${ }^{1}$, Dikshya \\ Maharjan $^{2}$
}

\author{
${ }^{1}$ Purbanchal University Girija Prasad Koirala college of Agriculture and Research Centre Gothgaun, Morang, Nepal \\ ${ }^{2}$ Tribhuvan University Institue of Science and Technology, Mahendra Ratna Multiple Campus Ilam, Nepal \\ *Corresponding Author
}

Received: 03 Jul 2021; Received in revised form: 19 Jul 2021; Accepted: 27 Jul 2021; Available online: 06 Aug 2021 (C)2021 The Author(s). Published by Infogain Publication. This is an open access article under the CC BY license (https://creativecommons.org/licenses/by/4.0/).

\begin{abstract}
Varietal screening of cucumber in the Eastern Terai of Nepal by using nine different varieties of cucumber i.e., F1-leader, Malini, Kangana, NS-404, Kamini, F1-solar, Encounter-962, Syngeta glossy and Bhaktapur local was conducted in Sundarharaicha, Morang during the month of February to June (2020) to find the best yielding variety. The experimental setup was designed on randomized complete block design having three replications and nine treatments. There was a significant difference among the varieties in terms of yield. NS-404 gave the highest yield (5468.66gm/harvest), highest number of harvest (8.80 harvests) and highest number of fruits/harvest (14.53 fruits/harvest). Encounter-962 gave the lowest yield (2689.73 gm/harvest). This study showed NS-404 as high yield variety and should be recommended in Sundarharaicha, Morang.
\end{abstract}

Keywords - Varietal screening, Cucumber, Fruit, Variety, Yield.

\section{INTRODUCTION}

Cucumber (Cucumis sativus L.) belongs to family Cucurbitaceae which is used as vegetable crop (Shinde et al., 2018). Cucumber is 4th most important cultivated vegetable after cabbage, onion and tomatoes in the world (Fareed et al., 2017). It is cylindrical in shape and size varies according to varieties(Christopher, 2020).Cucurbits are tropical in origin and are mainly cultivated in Africa, central America,and south east Asia (Maharjan et al., 2015). People consume cucumber in the form of salad, pickle, and vegetable. More than $90 \%$ of cucumber content is water. Besides its low caloric value, cucumber and other cucurbits are well served by potassium and folic acid but low in sodium (Akbar et al., 2015).

Globally, cucurbits are grown on an area of 8.5 million hectares with production of 17.9 million tons(Akbar et al., 2015). Agriculture is the backbone of Nepalese economy. Agriculture contributes on an average 33 percent to GDP and employs 65.7 Percent of the labor force in Nepal (Pandey et al., 2017). There are two major lean periods for the cucumber supply in Nepal. The first lean period extends from May to October and characterized by high temperature and long day photoperiodic condition and the second lean period is November-February, which is demonstrated by low temperature and short day photo period (Sharma et al., 2005).Due to lack of systematically organized planting the production of this vegetable is low. The nation has to invest heavy amount on the annual import of cucumber(Tripathy \& Behera, 2019). In Nepal, to date, very little research work have been performed on varietal screening of cucumber in Eastern Terai, due to which very few farmers are known about the cultivation practices of cucumber. Thus, the current investigation is aimed to assessing the performance of some promising varieties of cucumber in Gothgaun, Morang. 


\section{MATERIALS AND METHODS}

\subsection{EXPERIMENTAL SITE}

The experiment was conducted at G.P Koirala College of Agriculture and Research Centre Gothgaun; Morang. It lies at $26^{\circ} 40^{\prime} 2.56^{\prime \prime}$ latitude and $87^{\circ} 20^{\prime} 59.64^{\prime \prime}$ longitude and 135 meter above sea level. It also lies in the tropical region of Nepal. The research was conducted during the month of February to June (2020).

\subsection{EXPERIMENTAL MATERIAL}

The experiment was conducted under open field condition using nine different varieties of cucumber including one Bhaktapur local and eight hybrid varieties.

\subsection{EXPERIMENTAL DESIGN}

The experiment was conducted in Completely Randomized Block Design (RCBD), consisting three replications of each having nine treatments.Spacing between replications was $100 \mathrm{~cm}$ and between treatments was $50 \mathrm{~cm}$. Border gap was $100 \mathrm{~cm}$ around the experimental field. Total field size for research was $33 \mathrm{~m} \times 16 \mathrm{~m}$ consisting of 27 plots each of size $4 \mathrm{~m} \times 3 \mathrm{~m}$. Each plot consisted of 12 plants each, with spacing $100 \mathrm{~cm} \times 100 \mathrm{~cm}$. Out of 12 plants, centered 2 plant including other 3 were selected in random way from each plot as sample plants.

\section{TREATMENT DETAILS}

Total 9 variety of cucumber were selected as treatment in experimental setup.

$\mathrm{T} 1=$ Cucumber F1 leader

$\mathrm{T} 2=$ Malini

$\mathrm{T} 3=$ Kangana

$\mathrm{T} 4=\mathrm{NS}-404$

T5= Kamini 017 F1

T6= F1-solar

$\mathrm{T} 7=$ Encounter $962 \mathrm{~F} 1$

T8= Syngeta glossy cucumber

T9= Bhaktapur local

\subsection{SEEDLING PREPARATION FOR TRANSPLANTATION}

Seeds were soaked in water for $20 \mathrm{hrs}$ and were sown under protected conditions in polybags of size $15 \times 8 \mathrm{~cm}$ on $15^{\text {th }}$ February 2020.Two seeds per polybag were sown and kept inside the polyhouse with regular watering. Media used for seed germination was soil: sand: vermicompost in the ratio of 2:1:1 based on volume. Seed germination percentage of all varieties was $>85 \%$ except Bhaktapur local $<70 \%$.After complete germination of the seed and seed being ready for transplantation, the seedlings were transplanted with spacing of $100 \mathrm{~cm} \times 100$ cm P-P $\times$ R-R., keeping 12 plants per plot and 5 plants were sampled to document various observations. Transplantation was done on $5^{\text {th }}$ March 2020. Re transplantation was also done in case of damaged plants due to heavy rain and wind.

\subsection{FIELD PREPARATION, MANURE, FERTILIZATION, AND IRRIGATION}

Two plough one after another was done to make soil fine and porous on $19^{\text {th }}$ and $20^{\text {th }}$ February, respectively. Weeding was also done to remove weeds manually. Recommended dose of FYM 20 ton/ha was applied on field 7 days before seedling transplantation. Recommended dose of NPK $=120: 60: 50 \mathrm{~kg} / \mathrm{ha}$ was applied in the field about 4 hours before seedling transplantation. Urea was applied under four split doses at 15 days of interval. First irrigation was given on day of transplanting after transplanting of seedling then depending upon soil moisture condition irrigation was done and on days of application of fertilizer slight irrigation was done. The water requirement was almost met by natural rainfall. Trellis method of staking was done with bamboo stakes and bamboo sticks were used for training cucumber vines.

\subsection{DATA COLLLECTION TECHNIQUES}

Vegetative characteristics and flowering behaviors were recorded. 5 plants were selected from each plot as sample plant to record for different observations. Height of main stem $(\mathrm{cm})$, numbers of primary branches per vine were observed and average was calculated. Height was measured by using measuring tape. Fruit lengths $(\mathrm{cm})$, fruit circumference $(\mathrm{cm})$, were also measured by measuring tape and average was calculated. Number of fruits per plant, Marketable andNonmarketable fruits were observed, and average was calculated.

\subsection{FLORAL MEASUREMENTS}

Days to first female flower emergence after transplanting was on 23rdMarch 2020 and days to first male flower emergence after transplanting was on $24^{\text {th }}$ March 2020.Number of female flowers per plant and number of male flowers per plant were observed and average was calculated.

\subsection{DATA ANALYSIS}

All the recorded data were arranged systematically. A simple correlation and regression were established among the selected parameters with reference to Gomez and Gomez (1984). Different statistical tools as R and MSEXCEL were used for the analysis of variance and other data. 


\section{RESULTS AND DISCUSSION}

\subsection{PLANT HEIGHT (40 DAT)}

Among nine different varieties if cucumber, Bhaktapur local is the local variety and remaining are hybrid varieties. The plant height of different varieties was in range of 96.34 to $54.30 \mathrm{~cm}$. The highest plant height was found in Bhaktapur local i.e., $96.34 \mathrm{~cm}$ followed by NS 404(81.78cm), Malini $(77.02 \mathrm{~cm})$, F1-solar $(70.28 \mathrm{~cm})$, kamini $(67.56 \mathrm{~cm} 0$, kangana $(63.33 \mathrm{~cm})$, syngeta glossy $(59.72 \mathrm{~cm})$ and $\mathrm{F} 1$ leader $(59.32 \mathrm{~cm})$. The lowest plant height was found in Encounter- 962 i.e., $54.30 \mathrm{~cm}$. The average plant height was found to be $69.98 \mathrm{~cm}$ (Table 1).

It has been reported that the highest plant height was observed in Kathmandu local $(203 \mathrm{~cm})$ and the lowest plant height in kasinda (148.70) with average plant height $177.45 \mathrm{~cm}$ (Maharjan et al., 2015). There was a nonsignificant difference among different varieties on plant height.

\subsection{NUMBER OF BRANCH AT FINAL STAGE}

Among nine different varieties of cucumber, the greater number of branches was found in Bhaktapur local (5.26 branch) and the smaller number of branches was found in Encounter-962 (1.20 branch). Average number of branches was found to be 2.48 in every varieties of cucumber (Table 1). It has been found that the more number of branches was observed in Kathmandu local (primary branches $57.33 /$ plant and secondary branches 56.33/plant) and the less number of primary branches was observed in Malini (43.83/plant)(Maharjan et al., 2015). Also maximum number of branches per vine was recorded in genotype CUCUVAR-6 (11.26) while the lowest number of branches per vine was recorded in Supriya-100 (7.20) (Arunachalam, 2020). There was a highly significant difference among different varieties on number of branches at final stage.

\subsection{NUMBER OF FEMALE FLOWERS/PLANT}

The highest number of female flower (142.6 flowers/plant) was found in syngeta glossy followed by NS 404 (126 flowers/plant), Malini (108.33 flowers/plant), F1 leader (98.33 flowers/plant), kamini (98 flowers/plant), kangana (90 flowers/plant), F1-solar (86 flowers/plant), Encounter962 (83.33 flowers/plant). The lowest number of female flower (69.33flowers/plant) was found in Bhaktapur local. The average number of female flowers per plant was found to be 99.33 (Table 1).

It has been also reported that the highest number of female flower (27.33 flowers/plant) was recorded in Kamini and the lowest (7.83 flowers/plant) in Kusle at maximum flowering stage of plant ((Maharjan et al., 2015). Maximum number of female flowers in genotype CUCUVAR- 6 (28.53), followed by Prasad-100 (24.80) and minimum female flowers per vine was found in HY512 (14.00) (Arunachalam, 2020). There was a significant difference among different varieties on number of female flowers per plant.

Table 1: -Morphological character of different varieties cucumber in varietal screening Gothgaun, Morang, Nepal -2020

\begin{tabular}{llll}
\hline Varieties & $\begin{array}{c}\text { Plant height } \\
(\mathrm{cm})\end{array}$ & Number of branches at final & $\begin{array}{l}\text { Number of female } \\
\text { flowers/plants }\end{array}$ \\
\hline F1-leader & $59.52^{\mathrm{bc}}$ & $1.93^{\mathrm{c}}$ & $98.33^{\mathrm{bc}}$ \\
Malini & $77.02^{\mathrm{abc}}$ & $1.73^{\mathrm{c}}$ & $108.33^{\mathrm{bc}}$ \\
Kangana & $63.33^{\mathrm{bc}}$ & $1.46^{\mathrm{c}}$ & $90.00^{\mathrm{bc}}$ \\
NS-404 & $81.78^{\mathrm{ab}}$ & $3.80^{\mathrm{ab}}$ & $126.00^{\mathrm{ab}}$ \\
Kamini & $67.56^{\mathrm{bc}}$ & $2.13^{\mathrm{bc}}$ & $98.00^{\mathrm{bc}}$ \\
F1-solar & $70.28^{\mathrm{bc}}$ & $2.26^{\mathrm{bc}}$ & $86.00^{\mathrm{bc}}$ \\
Encounter-962 & $54.30^{\mathrm{c}}$ & $1.20^{\mathrm{c}}$ & $83.33^{\mathrm{c}}$ \\
Syngenta glossy & $59.72^{\mathrm{bc}}$ & $2.53^{\mathrm{bc}}$ & $142.66^{\mathrm{a}}$ \\
Bhaktapur local & $96.34^{\mathrm{abc}}$ & $5.26^{\mathrm{a}}$ & $69.33^{\mathrm{c}}$ \\
\hline Mean & 69.98 & 2.48 & 99.33 \\
SEM & 216.1 & 0.579 & 579.5 \\
LSD & $25.44(\mathrm{NS})$ & $1.71^{* *}$ & $41.66^{*}$ \\
CV & $21.00 \%$ & $39.87 \%$ & $24.23 \%$ \\
F test & NS & $* *$ & $*$
\end{tabular}

SEM: Standard error of mean; LSD: Least significant difference; CV: Coefficient of variation. 


\begin{tabular}{|c|c|c|}
\hline & $\begin{array}{l}\text { International Journal of Environment, Agriculture and Biotechnology } \\
\text { Vol-6, Issue-4; Jul-Aug, } 2021\end{array}$ & $(\theta)=$ \\
\hline IJEคB & $\begin{array}{c}\text { Journal Home Page Available: } \text { https://ijeab.com/ } \\
\text { Journal DOI: 10.22161/ijeab }\end{array}$ & \\
\hline
\end{tabular}

Article

*: Significant at $5 \%$ level of significance; **: Significant at $1 \%$ level of significance; $* * *$ : Significant at $0.1 \%$ level of significance; NS: Not significant.

\subsection{FRUIT LENGTH, DIAMETER AND WEIGHT}

Among nine different varieties of cucumber, the highest fruit length was found in Bhaktapur local $(26.51 \mathrm{~cm})$ followed by NS $404(24.32 \mathrm{~cm})$, syngeta glossy $(24.02 \mathrm{~cm})$, F1- solar $(23.99 \mathrm{~cm})$, Encounter-962 $(20.87 \mathrm{~cm})$, kamini $(20.85 \mathrm{~cm})$, kangana $(20.63 \mathrm{~cm})$ and Malini $(20.10 \mathrm{~cm})$. The lowest fruit length was found in F1-leader $(19.97 \mathrm{~cm})$. Average fruit length was found to be $22.36 \mathrm{~cm}$ (Table 2).

Similarly, the highest fruit diameter was found in Bhaktapur local $(6.32 \mathrm{~cm})$ followed by kamini $(5.35 \mathrm{~cm})$, syngeta glossy $(5.33 \mathrm{~cm})$, NS-404 $(5.14 \mathrm{~cm})$, kangana $(5.06 \mathrm{~cm})$, Encounter-962 $(5.02 \mathrm{~cm})$ and Malini and $\mathrm{F} 1-$ solar $(4.98 \mathrm{~cm})$. The lowest fruit diameter was found in $\mathrm{F} 1$ solar $(4.95 \mathrm{~cm})$. Average fruit diameter was found to be $5.23 \mathrm{~cm}$ (Table 2).

Also, the highest fruit weight was found in Bhaktapur local (635.75gm/fruit) followed by NS-404 (384.84gm/fruit), syngeta glossy $\quad(369.80 \mathrm{gm} /$ fruit $), \quad$ F1-solar (340.09gm/fruit), Kamini (311.85gm/fruit), Encounter-962 (292.05gm/fruit), kangana (288.64gm/fruit) and Malini (275.58gm/fruit). The lowest fruit weight was found in F1leader $(267.46 \mathrm{gm} /$ fruit). Average fruit weight was found to be $351.89 \mathrm{gm} /$ fruit (Table 2).

It has been also reported that the maximum fruit diameter was found in KARAN $(4.19 \mathrm{~cm})$ and the minimum fruit diameter was found in CUCUVAR-1 $(3.17 \mathrm{~cm})$. The maximum fruit length was found with CUCUVAR-6 $(19.33 \mathrm{~cm})$ and the minimum fruit length was recorded with CUCUVAR-5 $(12.38 \mathrm{~cm})$. The highest fruit weight were recorded in CUCUVAR-6 (177.60 gm) and the lowest fruit weight was recorded with AK-47 (139.20 gm) (Arunachalam, 2020). Fruit length, diameter and weight have been also differ by the use of chemicals like

Table 2: Yield attributing traits of different varieties of cucumber in varietal screening, Gothgaun, Morang, Nepal -2020

\begin{tabular}{lllll}
\hline Varieties & $\begin{array}{c}\text { Fruit length } \\
(\mathrm{cm})\end{array}$ & $\begin{array}{c}\text { Fruit diameter } \\
(\mathrm{cm})\end{array}$ & $\begin{array}{c}\text { Fruit weight } \\
(\mathrm{gm})\end{array}$ & $\begin{array}{c}\text { Yield/harvest } \\
(\mathrm{gm})\end{array}$ \\
\hline F1- leader & $19.97 \mathrm{c}$ & $4.98 \mathrm{~b}$ & $267.46^{\mathrm{b}}$ & $2740.13^{\mathrm{b}}$ \\
Malini & $20.10^{\mathrm{c}}$ & $4.98^{\mathrm{b}}$ & $276.58^{\mathrm{b}}$ & $3295.86^{\mathrm{b}}$ \\
Kangana & $20.63^{\mathrm{c}}$ & $5.06^{\mathrm{b}}$ & $288.64^{\mathrm{b}}$ & $2806.13^{\mathrm{b}}$
\end{tabular}

ethephon(Dhakal et al., 2019). There was a highly significant difference among the varieties on fruit length, fruit diameter and fruit weight. It has been also reported that the fruit length, diameter and weight of different varieties of cucumber depends on heredity and genetic variability (Kumar et al., 2013).

\subsection{YIELD PER HARVEST}

There was a significant difference among the varieties on yield. Among nine different varieties of cucumber, the highest yield per harvest was found in NS-404 (5468.66gm/harvest) followed by syngeta glossy (5442.73gm/harvest), Malini (3295.86gm/harvest), Kamini (3284gm/harvest), Bhaktapur local (3229.33gm/harvest), kangana (2806.13gm/harvest), F1-solar (2790.13gm/harvest) and F1-leader (2740.13gm/harvest). The lowest yield per harvest was found in Encounter-962 (2689.73gm/harvest). Average yield per harvest was found to be $3527.41 \mathrm{gm}$ (Table 2).

In this research, we found NS-404 as the best yield giving varieties. It has been shown that the Kamini variety was found superior as compared to the other varieties in terms of yield(Maharjan et al., 2015). It has been also shown that the maximum yield (tones/ hectare) was recorded in CUCUVAR-6 (35.99 t/ ha) and the lowest yield was found in HY-512 (19.55 t /ha)(Arunachalam, 2020). The experiment was conducted in the farmers' field conditions at Yampaphant, Tanahun, Nepal during April - July 2000 included one commercial cultivar namely Bhaktapur Local and the four exotic cultivars and hybrids namely Malini, Korean White, Japanese Green and Green Long. The hybrid Malini was found significantly more vigor and earlier (first picking at 42 days) and produced significantly higher number of fruits (252 thousands/ha) and significantly higher yield (69.6 t/ha) (Shakya et al., 2006). Also, the research conducted in owerri area of southeastern Nigeria having four different varieties if cucumber CU99, OHE/CU, MURANOF1 and AOA/CU, CU99 gives the highest yield (18840 kg/ha) (Umeh, 2018). 


\begin{tabular}{lllll} 
NS 404 & $24.32^{\mathrm{a}}$ & $5.14^{\mathrm{b}}$ & $384.84^{\mathrm{b}}$ & $5468.66^{\mathrm{a}}$ \\
Kamini & $20.85^{\mathrm{c}}$ & $5.35^{\mathrm{b}}$ & $311.85^{\mathrm{b}}$ & $3284.00^{\mathrm{b}}$ \\
F1- solar & $23.99^{\mathrm{b}}$ & $4.95^{\mathrm{b}}$ & $340.09^{\mathrm{b}}$ & $2790.13^{\mathrm{b}}$ \\
Encounter 962 & $20.87^{\mathrm{c}}$ & $5.02^{\mathrm{b}}$ & $292.05^{\mathrm{b}}$ & $2689.73^{\mathrm{b}}$ \\
Syngeta glossy & $24.02^{\mathrm{b}}$ & $5.33^{\mathrm{b}}$ & $369.80^{\mathrm{b}}$ & $5442.73^{\mathrm{a}}$ \\
Bhaktapur local & $26.51^{\mathrm{a}}$ & $6.32 \mathrm{a}$ & $635.75^{\mathrm{a}}$ & $3229.33^{\mathrm{b}}$ \\
\hline Mean & 22.36 & 5.23 & 351.89 & 3527.41 \\
SEM & 1.76 & 0.0554 & 5393 & 984121 \\
LSD & $2.30^{* * *}$ & $0.40^{* * *}$ & $127.11^{* * *}$ & $1717.09^{*}$ \\
CV & $5.94 \%$ & $4.49 \%$ & $20.86 \%$ & $28.12 \%$ \\
F test & $* * *$ & $* * *$ & $* * *$ & $*$ \\
\hline
\end{tabular}

SEM: Standard error of mean; LSD: Least significant difference; CV: Coefficient of variation.

*: Significant at $5 \%$ level of significance; **: Significant at $1 \%$ level of significance; ***: Significant at $0.1 \%$ level of significance; NS: Not significant.

\subsection{MARKETABLE FRUITS AND NON- MARKETABLE FRUITS PER HARVEST}

There was a significant difference among the varieties on the total number of marketable fruits per harvest. Among nine different varieties of cucumber, the highest number of marketable fruits per harvest was found in syngeta glossy (12.26 fruits/harvest) followed by NS-404 (12.06 fruits/harvest), Malini (8.33 fruits/harvest), F1-leader (7.80 fruits/harvest), Kamini (7.46 fruits/harvest), Kangana (7.20 fruits/harvest), Encounter-962 (6.66 fruits/harvest) and F1solar (6.40 fruits/harvest). The lowest number of marketable fruit per harvest was found in Bhaktapur local (3.73fruits/harvest). Average number of marketable fruits per harvest from each variety was found to be 7.99 fruits/harvest (Table 3).

Similarly, the highest number of nonmarketable fruits per harvest was found in Malini (3.40 fruits/harvest) followed by Kamini (3.06 fruits/harvest), NS-404 (2.46 fruits/harvest), kangana, F1-leader, Encounter-962 (2.33 fruits/harvest), syngeta glossy (2.20 fruits/harvest) and F1solar (1.93 fruits/harvest). The lowest number of nonmarketable fruits per harvest was found in Bhaktapur local (1.46 fruits/harvest). Average number of nonmarketable fruits per harvest from each variety was found to be 2.39 fruits/harvest (Table 3).

It has been reported that the total number of marketable fruit per plant was higher in Kamini (13.10 fruits/plant), whereas it was the lowest in Kusle (2.30 fruits/plant) (Maharjan et al., 2015). There was a nonsignificant difference among the varieties on the total number of nonmarketable fruits per harvest. Syngeta glossy and NS404 have almost produced same marketable fruit per harvest. Production of marketable fruit per harvest in syngeta glossy and NS-404 was almost four times double than Bhaktapur local.

\subsection{TOTAL NUMBER OF FRUITS PER HARVEST}

Among nine different varieties of cucumber, the highest number of fruits harvested was found in syngeta glossy (132 fruits) followed by NS404 (119.33 fruits), Malini (98.66 fruit), Kamini (91.33 fruits), F1-leader (89.33 fruits), Kangana (85.33 fruits), F1-solar (82.33 fruits) and Encounter-962 (78 fruits). The lowest number of fruits harvested was found in Bhaktapur local i.e., 66 fruits. Average number of fruits harvested was found to be 93.59 fruits (Table 3).

There was not a significant difference among the varieties on total number of fruits harvested. Late season planting may be the reason for Bhaktapur local having the lowest total number of fruits harvested. It has been also reported that kamini has the highest number of total fruit harvested (21.23 fruits) and Kusle has the lowest number of total fruit harvested (4.60 fruits) (Maharjan et al., 2015). 
Table 3: -Marketable fruit, non-marketable fruit, and total number of fruits of different varieties of cucumber in varietal screening, Gothgaun, Morang, Nepal-2020

\begin{tabular}{llll}
\hline Varieties & Marketable fruit/harvest & $\begin{array}{l}\text { Nonmarketable } \\
\text { fruit/harvest }\end{array}$ & $\begin{array}{l}\text { Total number of } \\
\text { fruit/harvests }\end{array}$ \\
\hline Cucumber F1leader & $7.80^{\mathrm{b}}$ & $2.33^{\mathrm{b}}$ & $89.33^{\mathrm{bc}}$ \\
Malini & $8.33^{\mathrm{b}}$ & $3.40^{\mathrm{a}}$ & $98.66^{\mathrm{abc}}$ \\
Kangana & $7.20^{\mathrm{b}}$ & $2.33^{\mathrm{ab}}$ & $85.33^{\mathrm{bc}}$ \\
NS 404 & $12.06^{\mathrm{a}}$ & $2.46^{\mathrm{ab}}$ & $119.33^{\mathrm{ab}}$ \\
Kamini 017 F1 & $7.46^{\mathrm{b}}$ & $3.06^{\mathrm{ab}}$ & $91.33^{\mathrm{bc}}$ \\
F1 solar & $6.40^{\mathrm{bc}}$ & $1.93^{\mathrm{ab}}$ & $82.33^{\mathrm{bc}}$ \\
Encounter 962 F1 & $6.66^{\mathrm{bc}}$ & $2.33^{\mathrm{ab}}$ & $78.00^{\mathrm{c}}$ \\
Syngeta glossy & $12.26^{\mathrm{a}}$ & $2.20^{\mathrm{ab}}$ & $132.00^{\mathrm{a}}$ \\
Bhaktapur local & $3.73^{\mathrm{c}}$ & $1.46^{\mathrm{b}}$ & $66.00^{\mathrm{c}}$ \\
\hline Mean & 7.99 & 2.39 & 93.59 \\
SEM & 3.41 & 0.8909 & 504.6 \\
LSD & $3.19^{* * *}$ & $1.63 \mathrm{NS}$ & $38.88 \mathrm{NS}$ \\
CV & $23.10 \%$ & $39.44 \%$ & $24 \%$ \\
F test & $* * *$ & $\mathrm{NS}$ & $\mathrm{NS}$ \\
\hline
\end{tabular}

SEM: Standard error of mean; LSD: Least significant difference; CV: Coefficient of variation.

*: Significant at $5 \%$ level of significance; **: Significant at $1 \%$ level of significance; ***: Significant at $0.1 \%$ level of significance; NS: Not significant.

\subsection{NUMBER OF HARVEST}

Among nine different varieties of cucumber, the highest number of harvesting was found in NS-404 (8.80 harvest) followed by Malini (8.46 harvest), syngeta glossy (8.06 harvest), F1-leader (7.33 harvest), kamini (6.93 harvest), kangana, Encounter-962 (6.66 harvest) and F1-solar (6.06 harvest). The lowest number of harvesting was found in Bhaktapur local (4 harvest). Average number of harvesting was found to be 7 . There was a highly significant difference among the varieties on total number of harvesting per plant (Table 4).

\subsection{NUMBER OF FRUITS PER HARVEST}

The total number of highest fruits per harvest was found in NS-404 (14.53 fruits/harvest) followed by syngeta glossy (14.46 fruits/harvest), Malini (11.46 fruits/harvest), Kamini (10.53 fruits/harvest), F1-leader (10.13 fruits/harvest), kangana (9.53 fruits/harvest), Encounter962 F1 (9 fruits/harvest) and F1-solar ( 8.33 fruits/harvest). The lowest number of fruits per harvest was found in Bhaktapur local (5.20 fruits/harvest). Average number of fruits per harvest was found to be 10.35. There was a highly significant difference among the varieties on total number of fruits per harvest (Table 4).

\subsection{BIOMASS YIELD}

There was a highly significant difference among the varieties on biomass yield. The highest biomass yield was found in Bhaktapur local (341.60gm) and the lowest biomass yield was found in F1-solar (75.33gm). Average biomass yield of cucumber variety was found to be $136.20 \mathrm{gm}$. There was a long gap in between Bhaktapur Local and other remaining varieties in case of biomass yield (Table 4). 
Table 4: Number of harvesting per plant, number of fruits per harvest and biomass yield of different varieties of cucumber in varietal screening, Gothgaun, Morang, Nepal -2020

\begin{tabular}{llll}
\hline Varieties & Number of harvesting & $\begin{array}{l}\text { Number of fruits per } \\
\text { harvest }\end{array}$ & $\begin{array}{c}\text { Biomass yield } \\
(\mathrm{gm})\end{array}$ \\
\hline Cucumber F1leader & $7.33^{\mathrm{d}}$ & $10.13^{\mathrm{c}}$ & $77.60^{\mathrm{c}}$ \\
Malini & $8.46^{\mathrm{ab}}$ & $11.46^{\mathrm{abc}}$ & $85.86^{\mathrm{c}}$ \\
Kangana & $6.66^{\mathrm{cd}}$ & $9.53^{\mathrm{c}}$ & $76.13^{\mathrm{c}}$ \\
NS 404 & $8.80^{\mathrm{a}}$ & $14.53^{\mathrm{a}}$ & $196.40^{\mathrm{b}}$ \\
Kamini 017 F1 & $6.93^{\mathrm{bcd}}$ & $10.53^{\mathrm{bc}}$ & $113.20^{\mathrm{bc}}$ \\
F1 solar & $6.06^{\mathrm{d}}$ & $8.33^{\mathrm{cd}}$ & $75.33^{\mathrm{c}}$ \\
Encounter 962 F1 & $6.66^{\mathrm{cd}}$ & $9.00^{\mathrm{cd}}$ & $98.93^{\mathrm{bc}}$ \\
Syngeta glossy & $8.06^{\mathrm{abc}}$ & $14.46^{\mathrm{ab}}$ & $160.80^{\mathrm{bc}}$ \\
Bhaktapur local & $4.00^{\mathrm{e}}$ & $5.20^{\mathrm{d}}$ & $341.60^{\mathrm{a}}$ \\
\hline Mean & 7 & 10.35 & 136.20 \\
SEM & 1.054 & 5.25 & 3410 \\
LSD & $1.77^{* *}$ & $3.96^{* *}$ & $101.07^{* * *}$ \\
CV & $14.66 \%$ & $22.14 \%$ & $12.87 \%$ \\
F test & $* *$ & $* *$ & $* * *$ \\
\hline
\end{tabular}

SEM: Standard error of mean; LSD: Least significant difference; CV: Coefficient of variation.

*: Significant at $5 \%$ level of significance; **: Significant at $1 \%$ level of significance; ***: Significant at $0.1 \%$ level of significance; NS: Not significant.

\section{CONCLUSION}

Among nine different varieties of cucumber, NS-404 was found to be the best yield giving variety and could be the best one for cultivation in Sundarharaicha municipality. Syngeta glossy is also the best yield giving variety after NS-404. All the varieties were damaged by cucurbits fruit fly. Malini and kamini gives highest number of nonmarketable fruits.

\section{ACKNOWLEDGEMENT}

We would like to express our heartfelt gratitude and sense of appreciation to Mr. Koshraj Upadhayaya who guided us and provided suggestions. We would like to acknowledge G. P. Koirala College of Agriculture and Research Centre for providing us the opportunity to conduct this study. We would also like to express our sincere gratitude to $\mathrm{Mr}$. Sashant Devkota for his valuable and unforgettable help and support.

\section{REFERENCES}

[1] Akbar, A., Ahmad, Z., Begum, F., \& Raees, N. (2015). Varietal Reaction of Cucumber against Cucumber mosaic virus. April, 833-838.
[2] Arunachalam, R. (2020). Utilization Pattern of the Mobile Agro Advisory Services Among the Farmers of Tamil Nadu. June.

[3] Christopher, A. O. (2020). Profitability of Cucumber Production. April.

[4] Dhakal, S., Karki, M., Subedi, P., \& GC, A. (2019). Effect Of Ethephon Doses On Vegetative Characters, Sex Expression and Yield Of Cucumber (Cucumis sativus cv. Bhaktapur Local) In Resunga Municipality, Gulmi, Nepal. International Journal of Applied Sciences and Biotechnology, 7(3), 370-377. https://doi.org/10.3126/ijasbt.v7i3.25284

[5] Fareed, G., Atiq, M., Abbas, M., Usman, M., Abbas, G., Haidar, Z., \& Hussain Qamar, S. (2017). Varietal Reaction of Cucumber (Cucumis sativus L.) Germplasm for Management of Fusarium Wilt of Cucumber (FWC). Advances in Zoology and Botany, 5(1), 1-3. https://doi.org/10.13189/azb.2017.050101

[6] Jalbani, N., Aftab, A. K., Bhutto, S., Ahmed, F., Mahroze, A. K., Ashique, T. K., Khan, A. R., Chandra, D., Nanda, P., Singh, S. R. S., Ghorai, A. K., Singh, S. R. S., Complex, W., Chandra, D., Nanda, P., Complex, W., Singh, S. R. S., Complex, W., Ghorai, A. K., ... Cabrera, S. G. (2014). Nutrient management for rice production. International Food Research Journal, 21(2), 161-165. http://www.plantphysiol.org/cgi/doi/10.1104/pp.107.10759 9 
[7] Kumar, S., Kumar, D., Kumar, R., Thakur, K. S., \& Dogra, B. S. (2013). Estimation of Genetic Variability and Divergence for Fruit Yield and Quality Traits in Cucumber ( Cucumis Sativus L .) in North-Western Himalays. 2(May 2016), 27-36. https://doi.org/10.13189/ujps.2013.010201

[8] Maharjan, R., Regmi, R., \& Poudel, K. (2015). Monitoring and Varietal Screening Cucurbit Fruit Fly, Bactrocera cucurbitae Coquillett (Diptera: Tephritidae) on Cucumber in Bhaktapur and Kathmandu, Nepal. International Journal of Applied Sciences and Biotechnology, 3(4), 714-720. https://doi.org/10.3126/ijasbt.v3i4.13988

[9] Mitu Baskota, B. S. Rao, R. S. (2006). KATHMANDU UNIVERSITY JOURNAL OF SCIENCE, ENGINEERING AND TECHNOLOGY VOL.II, No.1, FEBRUARY, 2006. Kathmandu University Journal of Science, Engineering and Technology, 2(1), 1-10.

[10] Pandey, G., Basnet, S., Pant, B., Bhattarai, K., Gyawali, B., \& Tiwari, A. (2017). An Analysis of Vegetables and Fruits Production Scenario in Nepal. Asian Research Journal of Agriculture, 6(3), 1-10. https://doi.org/10.9734/arja/2017/36442

[11] Shakya, S., Bhattarai, S., Tripathi, K., \& Sharma, M. (2006). Screening of Cucumber Germplasms for High Temperature and Long Day Photoperiodic Tolerance. Journal of the Institute of Agriculture and Animal Science, 27, 45-51. https://doi.org/10.3126/jiaas.v27i0.694

[12] Sharma, M., GC, Y., Tripathi, K., \& Bhattarai, S. (2005). Performance of Mahyco Green Long and Bhaktapur Local Cucumber Cultivars at Different Sowing Dates in Mid-Hill of Nepal. Journal of the Institute of Agriculture and Animal Science, 26, 163-166. https://doi.org/10.3126/jiaas.v26i0.671

[13] Shinde, P. B., Naik, K. V., Narayan, V., \& Shinde, B. D. (2018). Screening of Some Promising Cucumber Cultivars Against Fruit Flies ( Diptera: Tephritidae) Screening of Some Promising Cucumber Cultivars Against Fruit Flies ( Diptera: Tephritidae). November.

[14] Tripathy, P., \& Behera, B. (2019). Real time cucumber production benefits farmers and consumers. February 2020.

[15] Umeh, O. A. (2018). Evaluation of the performance of different varieties of cucumber (. Intl Journal of Agriculture and Rural Development, 21(1997), 3807-3815. 